\title{
Bylaws of the Western European
}

\section{Specialists Section}

\section{The latest revision, approved by the ACRL Board at the}

Midwinter Meeting. Changes are underlined.

\section{Article I. Name}

The name of this organization shall be the Western European Specialists Section of the Association of College and Research Libraries.

\section{Article II. Object}

The Section shall represent those librarians and others in the Association of College and Research Libraries (ACRL) who specialize or are otherwise professionally involved in the acquisition, organization, and use of information sources originating in or relating to Western European countries. This Section may cooperate with other professional groups, in regard to those aspects of library service that require special knowledge of sources from or concerning Western Europe.

\section{Article III. Membership}

Any member of the ACRL may elect membership in this Section. Every member has the right to vote and is eligible to hold office.

\section{Article IV. Meetings}

Sec. 1. Annual Meetings. The Section shall hold an annual business meeting at the time and place of the Annual Conference of the American Library Association.

Sec. 2. Special Meetings. Special meetings of the Section may be called at the discretion of the Executive Committee. All members of the Section shall receive notification of a special meeting at least one month prior to the scheduled date of the meeting.

Sec. 3. Quorum. Members of the Section present at an annual meeting shall constitute a quorum.

\section{Article V. Officers}

Sec. 1. Officers. The officers of the Section shall be a chairperson, a vice-chairperson/chairpersonelect, the immediate past chairperson, and a secretary.

Sec. 2. Terms. All officers shall serve for a term of one year which ends at the adjournment of the annual meeting.

Sec. 3. Vacancies. In the event of a vacancy in the office of the chairperson, the vicechairperson/chairperson-elect shall succeed to the office of the chairperson and shall continue in that office until the expiration of the term for which he/she was originally selected to serve as chairperson. If the office of the secretary becomes vacant, the chairperson shall appoint a member of the Section to that office. A vacancy in the office of vicechairperson/chairperson-elect shall be filled only by election.

\section{Article VI. Executive Committee}

Sec. 1. Composition. The Executive Committee shall consist of the officers, the chairpersons of standing committees, and one member-at-large elected for a one-year term.

Sec. 2. Powers and Duties. The Executive Committee shall conduct the business of the Section during the period between annual Section meetings. At each annual Section meeting the chairperson shall report on the work of the Executive Committee, at which time that work shall be subject to review by the membership of the Section. 
Sec. 3. Meetings. Regular meetings of the Executive Committee shall be held at the times and places of the Annual and Midwinter meetings of the American Library Association. Special meetings may be called at the discretion of the chairperson. Only members of the Executive Committee may vote at Executive Committee meetings, although all Executive Committee meetings shall be open to all members of the Section.

Sec. 4. Quorum. A majority of members constitutes a quorum at any meeting of the Executive Committee.

\section{Article VII. Committees}

Sec. 1. Standing Committees. Standing committees to consider matters of concern to the Section that require continuity of attention may be authorized by the Section at the annual Section meeting. The size, name, and purpose of a standing committee shall be specified at the time of its authorization. Members of a standing committee shall serve overlapping terms of two years each. In order to set in motion a rotation of committee members, however, some of the initial members of a newly established committee shall be appointed for terms of three years. A member of a committee may be reappointed for a second term and for a third term, but no person shall serve more than six consecutive years on a single committee. The vicechairperson/chairperson-elect shall appoint committee members to fill the vacancies due to occur during his/her term as chairperson. The vicechairperson/chairperson-elect shall also designate the chairpersons of all committees which will function during his/her term as chairperson of the Section. Unexpected vacancies on a committee shall be filled by a special appointment made by the chairperson of the committee with the approval of the chairperson of the Section. A standing committee may be discontinued by a majority vote of the members present and voting at an annual Section meeting.

Sec. 2. Special (Ad Hoc) Committees. Special committees for the performance of particular assignments may be appointed at any time by the chairperson after consultation with the other members of the Executive Committee. Such special committees shall be discontinued at the end of the term of the chairperson who appointed them unless extended by the new chairperson. No special committee shall continue to function for more than two years without authorization by the Section.

Sec. 3. Discussion Groups. Informal discussion groups, to meet under the auspices of the Section at the time and place of the Annual or Midwinter meetings of the American Library Association, may be formed by any five or more members of the Section with the approval of the chairperson.

\section{Article VIII. Nominations and Elections}

Sec. 1. Nominations. The vice-chairperson/ chairperson-elect shall appoint a Nominating

\section{Midwest Library Service}

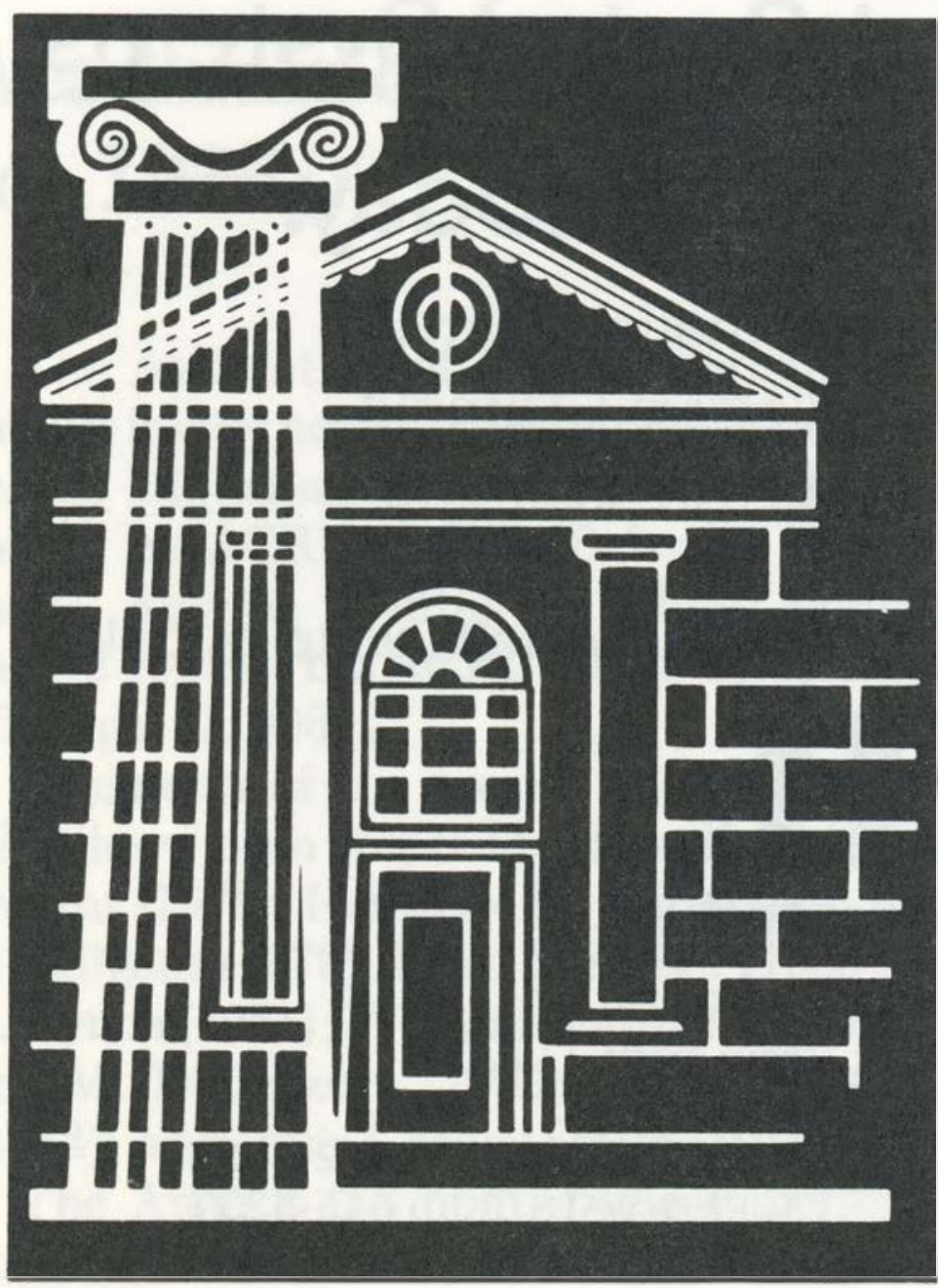

\section{You won't find more specialized service ... anywhere}

College and university librarians: If there are gaps in services being rendered by your current library jobber, then Midwest Library Service may be what you're looking for. Midwest has specialized in service to college and university libraries for 24 years-so long that providing books from even the most obscure publisher is standard practice. For prompt, efficient service on all orders, contact Midwest Library Service.

\section{Midwest Library Service \\ 11443 St. Charles Rock Road Bridgeton, MO 63044}

Call toll-free (800) 325-8833

Missouri librarians call toll-free (800) 392-5024 Canadian librarians call collect (800) 527-1659 
Committee of at least three members, designating one member as Committee chairperson. No member of the Nominating Committee shall be currently serving on the Executive Committee. The Nominating Committee shall choose a slate of at least two nominees for each of the offices of $(a)$ vice-chairperson/chairperson-elect, $(b)$ secretary, and $(c)$ member-at-large. Additional nominations for these offices may be made by petitions signed by no fewer than five Section members. Nominations put forth by the Nominating Committee, as well as any additional nominations made by petition, shall be filed both with the Executive Director of the ACRL and with the secretary of the Section within the deadlines prescribed for nominations by the ACRL. All nominees must be members in good standing of the Section and must consent to candidacy in writing.

Sec. 2. Elections. Elections shall be conducted by mail ballot. For each office, the candidate receiving a plurality of the votes cast shall be elected. In case of a tie vote the successful candidate shall be determined by lot.

\section{Article IX. Amendments}

Sec. 1. Proposals. Amendments to these Bylaws may be proposed in writing by the Executive Com- mittee, by a committee appointed specifically for the purpose, or by any five members of the Section. Proposals shall be filed with the secretary at least three months before the annual meeting.

Sec. 2. Notification. A copy of any proposed amendments to be voted on at the annual meeting shall be mailed by the secretary to each member of the Section at least thirty days before the annual meeting or shall be announced in College $b$ Research Libraries News in an issue appearing prior to the annual meeting.

Sec. 3. Voting. An amendment approved by two-thirds of the members voting in a mail vote or by two-thirds of the members present and voting at an annual meeting of the Section shall be carried.

\section{Article X. General Provisions}

Wherever these Bylaws make no specific provisions, the organization of and procedures in the Section shall correspond to those set forth in the ACRL Constitution and Bylaws.

\section{Article XI. Temporary Provisions}

These Bylaws shall take effect upon the adjournment of the meeting at which they are adopted.

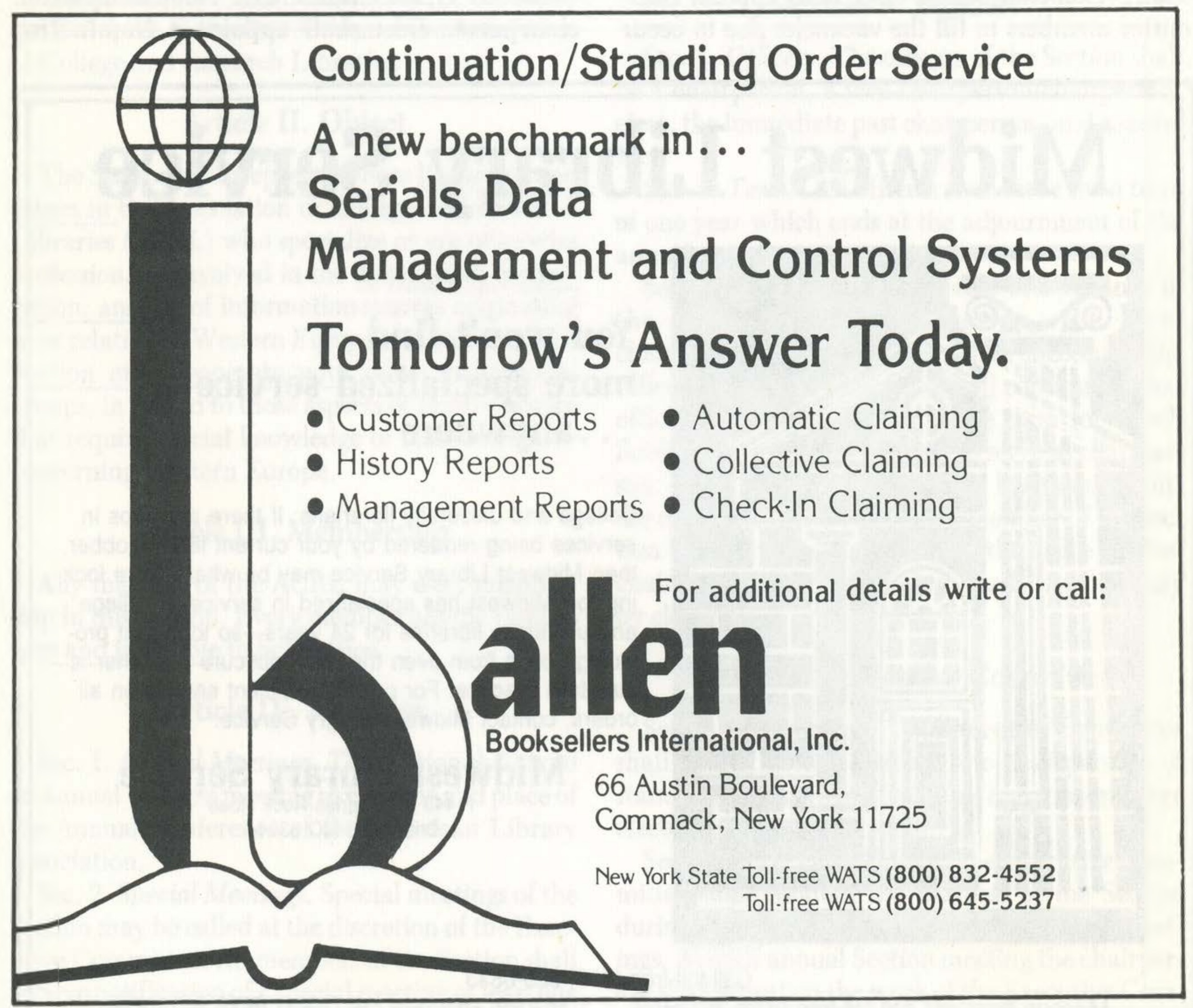




\section{Smith named librarian of the year}

Jessie Carney Smith, university librarian at Fisk University, Nashville, Tennessee, has been awarded the ACRL Academic or Research Librarian of the Year Award for 1985. The Association of College and Research Libraries and the Baker \& Taylor Company will present the award to Smith on July 8 at the ACRL reception at Annual Conference in Chicago.

The award cites Smith for attention to the improvement of academic library services, resources, and opportu-

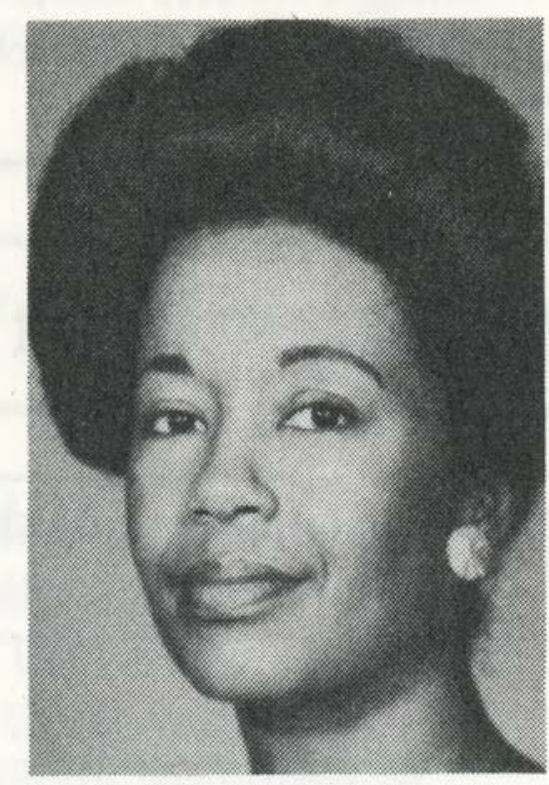

Jessie Carney Smith nities for Blacks. The ci-

tation reads, "As a result of her unswerving commitment, important progress has been made, and this selfless dedication to worthy causes has made her an inspiration not only to her own race but to the rest of us as well."

Smith was also honored for her work as university librarian at Fisk since 1965, where she has guided the development of new programs, the establishment of new research resources, and the construction of new plant facilities. She has also lectured widely, directed many colloquia and institutes, and sought and obtained funding for a number of research and training programs. She has long been an adjunct professor in the Peabody Library School, she has been a frequent consultant on academic library matters both in this country and abroad, and she has filled elective and appointive offices in professional organizations.

The award also mentioned her several books and "her many articles in the professional press which have been cited for their wisdom and leadership." One of her most recent books is Ethnic Genealogy: A Research Guide, published in 1983 by Greenwood Press.

The ACRL Academic or Research Librarian of the Year Award Committee that selected Smith for the award consisted of the following persons: Patricia G. Oyler (chair), Associate Professor, Simmons College, Graduate School of Library and Information Science, Boston; Cynthia B. Duncan, Dean of Library Services, Old Dominion University, Norfolk; Elinor Ebeling, Director, Learning Resources, Brookdale Community College, Lincroft, New Jersey; David Kaser, School of Library and Information Science, Indiana University, Bloomington; William Moffett, Director of Libraries, Oberlin College, Oberlin, Ohio; and Charles Osburn, Dean and University Librarian, University of Cincinnati, Cincinnati, Ohio.

\section{Academic or Research Librarian of the Year Award for 1986}

The Association of College and Research Libraries invites nominations for the Academic or Research Librarian of the Year Award, presented jointly by ACRL and the Baker \& Taylor Company. Anyone wishing to submit nominations should contact the ACRL office, $50 \mathrm{E}$. Huron St., Chicago, IL 60611.

Recipients of the award since its inception in 1978 have been Keyes D. Metcalf and Robert B. Downs (1978); Henriette D. Avram and Frederick G. Kilgour (1979); Evan I. Farber (1980); Beverly P. Lynch (1981); William Budington (1982); Richard M. Dougherty (1983); Richard D. Johnson (1984); and Jessie Carney Smith (1985).

The Awards Committee selects persons to receive the award in accordance with the following guidelines:

Purpose: To recognize an individual member of the library profession who has made an outstanding national or international contribution to aca- demic or research librarianship and library development.

Criteria: Individuals nominated should have demonstrated achievements in such areas as:

1. Service to the organized profession through ACRL and related organizations.

2. Significant and influential research on academic or research library service.

3. Publication of a body of scholarly and/or theoretical writing contributing to academic or research library development.

4. Planning and implementing a library program of such exemplary quality that it has served as a model for others.

5. Nominee does not have to meet all of the above criteria.

Rules: The award shall be made each year at a time and place to be determined by the ACRL Board of Directors. Announcement of the award shall be made by the ACRL president at a time and 
place to be determined by the Board of Directors. If, in the opinion of the Award Committee, no worthy candidate is nominated in a given year, the award will not be presented that year.

Nominations: Nominations for the award must be returned to the chair of the Academic/Research Librarian of the Year Award Committee and must be postmarked no later than December 1, 1985. Nominations must be submitted in quintuplicate and should be accompanied by a statement of sup- porting reasons and a copy of the nominee's resume. Please do not solicit supporting letters seconding your nomination. Such letters will not be considered in the Award Committee's decision.

Nature of the award: The Academic/Research Librarian of the Year Award shall consist of $\$ 3,000$ and an appropriate citation.

For more information please contact Sandy Whiteley, ACRL/ALA, 50 E. Huron St., Chicago, IL 60611; (312) 944-6780.

I nominate

(name and present address)

(Please list achievements of your nominee on a separate sheet.)

Nominated by

Address

Please return no later than December 1, 1985, to:

Academic or Research Librarian Award

Association of College and Research Libraries, ALA

50 East Huron Street

Chicago, IL 60611-2795

\section{Stocked Any Language Courses Lately?}

A growing number of libraries are acquiring our self-instructional book / cassette courses for use by their patrons. We offer comprehensive courses in:

$\begin{array}{cccc}\text { Afrikaans } & \text { French } & \text { Japanese } & \text { Swahili } \\ \text { Amharic } & \text { German } & \text { Korean } & \text { Swedish } \\ \text { Arabic } & \text { Greek } & \text { Mandarin } & \text { Tagalog } \\ \text { Bulgarian } & \text { Haitian Creole } & \text { Norwegian } & \text { Thai } \\ \text { Cambodian } & \text { Hausa } & \text { Persian } & \text { Turkish } \\ \text { Cantonese } & \text { Hebrew } & \text { Polish } & \text { Twi } \\ \text { Danish } & \text { Hindi } & \text { Portuguese } & \text { Urdu } \\ \text { Dutch } & \text { Hungarian } & \text { Russian } & \text { Vietnamese } \\ \text { English } & \text { Indonesian } & \text { Serbo-Croatian } & \text { Yoruba } \\ \text { Finnish } & \text { Italian } & \text { Spanish } & \text { Zulu }\end{array}$

Free 32-page catalog available from: 


\section{We know you're well read - so are we.}

\section{We're Mountainside Publishing}

We're one of the few totally independent journal publishers in the field. And, since 1974, we've been providing publications that make your work easier and more meaningful.

How well do you know Mountainside? If you're not familiar with more than one of the following publications, just ask a colleague. You'll find we are very well read.

\section{The Journal of Academic Librarianship}

Articles, Features, and Book Reviews for the Academic Library Professional The most substantial bimonthly publication in the profession. Penetrating articles, reports, and opinion pieces - plus over 160 summaries of critical reviews in each issue.

\section{Research Strategies}

A journal of library concepts and instruction

The quarterly source for library instruction guidance and perspective. Fast-paced and thorough. Each issue provides the logic, tools, and methods for effective library research. Full of valuable contributions from your colleagues in the field.

\section{Library Issues \\ Briefings for Faculty and Administrators}

A bimonthly newsletter that addresses the most crucial topics for academic libraries in the 80's. Pertinent facts, precise presentation, and clear interpretation of the issues that matter.

\section{Plus}

\section{Reference Book Guides}

Specially formatted instruction cards that serve as a "librarian's assistant." Visually oriented, instructions that fit right inside the reference book cover. Helpful for even the most inexperienced user. Over 300 titles to date.

\section{Mountainside Publishing keeps you informed, prepared and involved.}

\section{Become a Mountainside subscriber. Call or write for information today.}

Mountainside Publishing, Inc. 321 S. Main Street / P. O. Box 8330 / Ann Arbor, Michigan 48107 (313) 662-3925

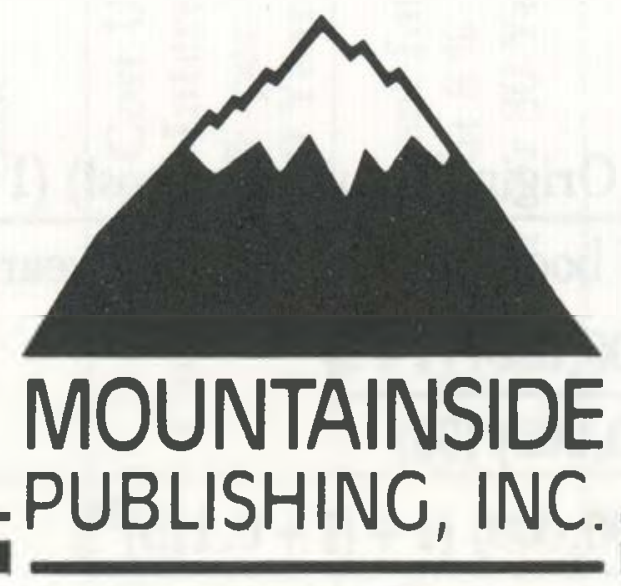

